\title{
Biological control of Pythium ultimum by Stenotrophomonas maltophilia W81 is mediated by an extracellular proteolytic activity
}

\author{
Colum Dunne, ${ }^{1,2}$ Jer J. Crowley, ${ }^{1}$ Yvan Moënne-Loccoz, ${ }^{1} \dagger$ \\ David N. Dowling, ${ }^{1} \ddagger$ Frans J. de Bruijn ${ }^{2}$ and Fergal O'Gara ${ }^{1}$
}

Author for correspondence: Fergal O'Gara. Tel: +35321 272097. Fax: +35321275934. e-mail: f.ogara@bureau.ucc.ie

1 Department of Microbiology, University College Cork, Cork, Ireland

2 MSU-DOE Plant Research Laboratory and Department of Microbiology, Michigan State University, East Lansing, MI 48824, USA
Stenotrophomonas maltophilia strain W81, isolated from the rhizosphere of field-grown sugar beet, produced the extracellular enzymes chitinase and protease and inhibited the growth of the phytopathogenic fungus Pythium ultimum in vitro. The role of these lytic enzymes in the interaction between W81 and $P$. ultimum was investigated using Tn5 insertion mutants of W81 incapable of producing extracellular protease (W81M1), extracellular chitinase (W81M2) or the two enzymes (W81A1). Lytic enzyme activity was restored in W81A1 following introduction of a $15 \mathrm{~kb}$ cosmid-borne fragment of W81 genomic DNA. Incubation of $P$. ultimum in the presence of commercial purified protease or cell-free supernatants from cultures of wild-type W81, the chitinase-negative mutant W81M2 or the complemented derivative W81A1(pCU800) resulted in hyphal lysis and loss of subsequent fungal growth ability once re-inoculated onto fresh plates. In contrast, commercial purified chitinase or cell-free supernatants from cultures of the protease-negative mutant W81M1 or the chitinase- and protease-negative mutant W81A1 had no effect on integrity of the essentially chitin-free Pythium mycelium, and did not prevent subsequent growth of the fungus. In soil microcosms containing soil naturally infested by Pythium spp., strains W81, W81M2 and W81A1(pCU800) reduced the ability of Pythium spp. to colonize the seeds of sugar beet and improved plant emergence compared with the untreated control, whereas W81A1 and W81M1 failed to protect sugar beet from damping-off. Wild-type W81 and its mutant derivatives colonized the rhizosphere of sugar beet to similar extents. It was concluded that the ability of S. maltophilia W81 to protect sugar beet from Pythium-mediated damping-off was due to the production of an extracellular protease.

Keywords: biological control, Pythium ultimum, sugar beet, Stenotrophomonas maltophilia, protease

\section{INTRODUCTION}

The interactions between pathogenic or deleterious soil micro-organisms and the plant root take place in the rhizosphere, a complex environment in which those

\footnotetext{
†Present address: Ecologie Microbienne du Sol, Université Claude Bernard (Lyon 1), 69622 Villeurbanne cedex, France.

$\ddagger$ Present address: Department of Applied Biology and Chemistry, Carlow
} Regional Technical College, Carlow, Ireland. detrimental micro-organisms are themselves subject to competition, antagonism, parasitism and/or predation by other soil organisms such as fungi, bacteria, viruses, nematodes and protozoa (Atlas \& Bartha, 1993; Cook et al., 1995). In certain soils, which have been referred to as suppressive, such interactions may be sufficient to prevent disease development (Scher \& Baker, 1982; Alabouvette et al., 1993). Disease suppression may also be achieved in other soils following the introduction of selected biological control agents into the soil or the 
rhizosphere. Beneficial micro-organisms of interest for biocontrol of soil-borne pathogens and pests have been identified among fungi, actinomycetes and bacteria and they represent a promising alternative to the use of chemical pesticides for crop protection (Becker \& Schwinn, 1993; Cook, 1993; Dunne et al., 1996, 1997; Cronin et al., 1997; Keel \& Défago, 1997). In addition to their beneficial properties, a key feature of effective biocontrol agents is their ability to persist in soil and aggressively colonize the rhizosphere. Therefore, it has been proposed that isolation of biocontrol microorganisms indigenous to an environment similar to that in which they will be required to function may ensure greater efficacy of plant protection (Cook, 1993).

Antibiosis is perhaps the most-studied mechanism of biocontrol in bacteria. Several secondary metabolites with antifungal properties have been identified, for example phenazines, pyrrol derivatives, hydrogen cyanide and phloroglucinols (reviewed by Dowling \& O'Gara, 1994). Their contribution to the protection of plants against fungal root diseases by pseudomonads has been documented using genetic and biochemical approaches (Thomashow \& Weller, 1988; Fenton et al., 1992; Voisard et al., 1994), and some of these compounds have been successfully quantified in the rhizosphere (Keel et al., 1992). In addition, niche exclusion, competition for nutrients such as iron (mediated through production of fluorescent siderophores) or carbon sources, induced resistance, parasitism and extracellular lytic enzymes have been implicated in plant protection by bacteria (Lemanceau \& Alabouvette, 1991; O'Sullivan \& O'Gara, 1992; Chernin et al., 1995; Kobayashi et al., 1995; Leeman et al., 1995; Keel \& Défago, 1997).

Under in vitro conditions, exposure of phytopathogenic fungi to lytic enzymes such as chitinases, proteases, amylases or glucanases can result in the degradation of the structural matrix of fungal cell walls (Oppenheim \& Chet, 1992; Lorito et al., 1994). The role of lytic enzymes produced by the mycoparasitic fungus Trichoderma harzianum in biological control of fungal pathogens has been demonstrated (Geremia et al., 1993; Haran et al., 1996), and overproduction of an inducible extracellular protease by copy number effect resulted in enhanced biocontrol efficacy (Flores et al., 1997). Transgenic biocontrol agents and plants with a conferred ability to produce antifungal chitinases have also been reported (Oppenheim \& Chet, 1992). However, in contrast to the attention devoted to lytic enzymes produced by biocontrol fungi, comparatively fewer studies have focused on bacterial production of lytic enzymes for biocontrol of fungal pathogens, and only circumstantial evidence was provided in the latter to attribute observed biocontrol abilities to lytic enzyme production (Mitchell \& Hurwitz, 1965; Fridlender et al., 1993; Chernin et al., 1995 ; Kobayashi et al., 1995).

The diversity of biocontrol traits in most soil bacteria other than Pseudomonas spp., Burkbolderia spp. and Bacillus spp. remains virtually untapped. In this study, a rhizosphere isolate obtained from field-grown sugar beet, Stenotrophomonas (previously Pseudomonas and then Xanthomonas) maltophilia W81, was studied that inhibited the fungal pathogen Pythium ultimum under laboratory conditions. Mutant derivatives of W81 were developed through transposon insertion and were used to demonstrate that protection of sugar beet against Pythium-mediated damping-off by the wild-type bacterial strain was due to its ability to produce an extracellular protease.

\section{METHODS}

Isolation from the sugar beet rhizosphere of a strain of $S$. maltophilia antagonistic to $P$. ultimum. $S$, maltophilia strain W81 was isolated on S1 medium (Gould et al., 1985) from the rhizosphere of sugar beet grown near Glanworth (Co. Cork, Ireland) at a field site chosen on the basis of its lack of history of damping-off disease of sugar beet. The strain was selected for its ability to inhibit growth of the fungal pathogen $P$. ultimum (obtained from the Commonwealth Mycological Institute, Egham, Surrey, England) on a range of solid media, i.e. Luria-Bertani (LB; Sambrook et al., 1989) agar, sucroseasparagine (SA; Scher \& Baker, 1982) agar, potato dextrose agar (PDA; Oxoid), malt extract agar (MEA; Oxoid), and nutrient agar (NA; Oxoid), as follows. Strain W81 was grown overnight in $10 \mathrm{ml} \mathrm{LB}$ broth $\left(28^{\circ} \mathrm{C}\right.$, with shaking). The cells were washed twice in quarter-strength Ringer's solution (Oxoid), resuspended in $100 \mu \mathrm{l}$ quarter-strength Ringer's solution and streaked onto the plates. After a $48 \mathrm{~h}$ incubation at $28^{\circ} \mathrm{C}$, plugs of $P$. ultimum freshly grown on SA agar were placed in the centre of the plates, which were then incubated at $28{ }^{\circ} \mathrm{C}$ for a further $3-5 \mathrm{~d}$ prior to assessing fungal growth.

Micro-organisms, plasmids and growth conditions. Bacterial strains and plasmids used in the study are described in Table 1. Strain W81 was identified as S. maltophilia (Swings et al., 1983; Palleroni \& Bradbury, 1993) based on the results of BIOLOG biochemical tests and fatty acid methyl ester analysis (DSM, Braunschweig, Germany). S. maltophilia W81 and its mutants were routinely grown in LB broth (at $28^{\circ} \mathrm{C}$ ), Pseudomonas fluorescens strain F113 in SA broth (at $28^{\circ} \mathrm{C}$ ) and Escherichia coli in LB broth (at $37^{\circ} \mathrm{C}$ ). Where appropriate, antibiotics were added to growth media at the following concentrations: streptomycin, $100 \mu \mathrm{g} \mathrm{ml}^{-1}$; kanamycin, $25 \mu \mathrm{g} \mathrm{ml}^{-1}$; tetracycline, $25 \mu \mathrm{g} \mathrm{ml}^{-1}$; and chloramphenicol, $30 \mu \mathrm{g} \mathrm{ml}^{-1}$. Bacteria were maintained in glycerol solutions at $-20^{\circ} \mathrm{C}$. P. ultimum was kept on corn meal agar (Difco).

Plate assays for chitinolytic and proteolytic activity. Chitinolytic activity was assessed using a solid minimal media containing $\mathrm{K}_{2} \mathrm{HPO}_{4}\left(0.8 \mathrm{~g} \mathrm{l}^{-1}\right), \mathrm{KH}_{2} \mathrm{PO}_{4}\left(0 \cdot 2 \mathrm{~g} \mathrm{l}^{-1}\right),\left(\mathrm{NH}_{4}\right)_{2} \mathrm{SO}_{4}$ $\left(0.5 \mathrm{~g} \mathrm{l}^{-1}\right), \mathrm{MgSO}_{4} .7 \mathrm{H}_{2} \mathrm{O}\left(0 \cdot 2 \mathrm{~g} \mathrm{l}^{-1}\right), \mathrm{CaCl}_{2} .2 \mathrm{H}_{2} \mathrm{O}\left(10 \mathrm{mg} \mathrm{l}^{-1}\right)$, $\mathrm{FeCl}_{3} \cdot 6 \mathrm{H}_{2} \mathrm{O}\left(10 \mathrm{mg} \mathrm{l}^{-1}\right), \mathrm{ZnSO}_{4} .7 \mathrm{H}_{2} \mathrm{O}\left(1 \mathrm{mg} \mathrm{l}^{-1}\right)$, Casamino acids $\left(2 \mathrm{~g} \mathrm{l}^{-1}\right)$, purified agar $\left(15 \mathrm{~g} \mathrm{l}^{-1}\right)$ and an equal volume of a $1 \%(\mathrm{w} / \mathrm{v})$ colloidal chitin suspension (Sigma). Proteolytic activity was studied on plates containing skim milk $\left(100 \mathrm{~g}^{-1}\right)$, yeast extract $\left(1.5 \mathrm{~g} \mathrm{l}^{-1}\right)$ and technical agar $\left(15 \mathrm{~g} \mathrm{l}^{-1}\right)$.

Bacteria were streaked directly onto the plates or, alternatively, $100 \mu$ f filter-sterilized cell-free supernatant of bacterial cultures (in SA or LB), obtained after concentration $(\times 500)$ using an Amicon ultra-filtration unit, were spotted onto the centre of the plates. The plates were incubated overnight at $28^{\circ} \mathrm{C}$. Both chitin- and skim-milk-containing plates are opaque and enzyme activity was identified by the development of a zone of clearing (halo) around the colonies and the cellfree supernatant spots. 
Table 1. Bacterial strains and plasmids

\begin{tabular}{|c|c|c|}
\hline Strain or plasmid & Relevant characteristics & $\begin{array}{l}\text { Source } \\
\text { or reference }\end{array}$ \\
\hline \multicolumn{3}{|l|}{ Strains } \\
\hline \multicolumn{3}{|l|}{ S. maltophilia } \\
\hline W81 & Wild-type, $\mathrm{Sm}^{\mathrm{r}} \mathrm{Km}^{\mathrm{r}} \mathrm{Phl}^{-} \mathrm{Hcn}^{-} \mathrm{Flu}^{-} \mathrm{Chi}^{+} \mathrm{Prt}^{+}$ & This study \\
\hline W81M1 & $\mathrm{Tc}^{\mathrm{r}} \operatorname{Prt}^{-}, \mathrm{Tn} 5-764 \mathrm{~cd}$ mutant of W81 & This study \\
\hline W81M2 & $\mathrm{Tc}^{\mathrm{r}} \mathrm{Chi}^{-}, \mathrm{Tn} 5-764 \mathrm{~cd}$ mutant of W81 & This study \\
\hline W81A1 & $\mathrm{Tc}^{\mathrm{r}} \mathrm{Chi}^{-} \mathrm{Prt}^{-}, \mathrm{Tn} 5-\mathrm{B} 50$ mutant of W81 & This study \\
\hline W81A1(pCU800) & $\mathrm{Tc}^{\mathrm{r}}-\mathrm{Cm}^{\mathrm{r}}$-complemented mutant of W81A1 & This study \\
\hline \multicolumn{3}{|l|}{ P. fluorescens } \\
\hline F113LacZY & $\mathrm{Phl}^{+} \mathrm{Hcn}^{+} \mathrm{Flu}^{+} \mathrm{LacZY}^{+}$ & Fedi et al. (1996) \\
\hline \multicolumn{3}{|l|}{ E. coli } \\
\hline HB101 & recA bsdB bsdM strA pro leu thi & $\begin{array}{l}\text { Boyer \& Roulland- } \\
\text { Dussoix (1969) }\end{array}$ \\
\hline MC1061 & ara leu lacX74 galU galK hsdB bsdM strA & $\begin{array}{l}\text { Casadaban \& Cohen } \\
(1980)\end{array}$ \\
\hline $\mathrm{DH} 5 \alpha$ & $\begin{array}{l}\phi 80 \text { lac } Z \Delta \mathrm{M} 15 \Delta(\text { lac ZYA-argF }) \mathrm{U} 169 \text { hsdR17 } \\
\text { recA1 endA1 thi-1 }\end{array}$ & $\begin{array}{l}\text { Sambrook et al. } \\
\text { (1989) }\end{array}$ \\
\hline LE392 & $\begin{array}{l}\mathrm{F}^{-}, \text {bsdR514 supE44 supF58 lacY1 galT22 } \\
\text { metB1 trpR55 } \lambda^{-}\end{array}$ & $\begin{array}{l}\text { Sambrook et al. } \\
\text { (1989) }\end{array}$ \\
\hline $\mathrm{S} 17-1$ & 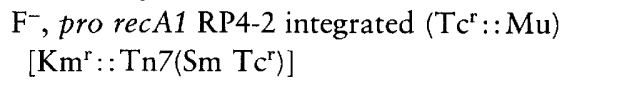 & Simon et al. (1983b) \\
\hline \multicolumn{3}{|l|}{ Plasmids } \\
\hline pSUP106 & $\begin{array}{l}\text { Broad-host-range cosmid vector, IncQ } \mathrm{Cm}^{\mathrm{r}} \\
\mathrm{Tc}^{\mathrm{r}}\end{array}$ & Simon et al. (1983a) \\
\hline pCU800 & pSUP106 with a $15 \mathrm{~kb}$ insert from W81 & This study \\
\hline pRK2013 & $\mathrm{Mob}^{+} \mathrm{Tra}^{+} \mathrm{Km}^{\mathrm{r}}$ & Ditta et al. (1980) \\
\hline pSUP102:: Tn5-B50 & $T c^{r}$ & Simon et al. (1989) \\
\hline pRL1063a & $\mathrm{Km}^{r} \operatorname{LuxAB}^{+}$ & Wolk et al. (1991) \\
\hline pRL764cd & $\mathrm{Tc}^{\mathrm{r}} \mathrm{LuxAB}^{+}$ & This study \\
\hline
\end{tabular}

Polyacrylamide gel assays for chitinolytic and proteolytic activity. Filter-sterilized concentrated cell-free supernatants obtained as described above were electrophoresed on denaturing and non-denaturing polyacrylamide gels (Sigma) in which $1 \%$ skim milk or $1 \%$ chitin had been incorporated. Following electrophoresis, and where appropriate, SDS was removed from the polyacrylamide gels by washing them in Triton X-100. The gels were then incubated overnight at $28^{\circ} \mathrm{C}$ and stained with Coomassie brilliant blue R250 stain. After a brief period of destaining, bands of clearing corresponding to particular protein bands were observed. Where $1 \%$ chitin was incorporated into the polyacrylamide gels, chitinolytic activity was visible without the requirement for staining.

Biochemical quantification of extracellular proteolytic activity. Bacterial extracellular proteolytic enzyme production was quantified colorimetrically, using a modification of the procedure described by McKellar et al. (1981). The strains were grown overnight at $28^{\circ} \mathrm{C}$ (with shaking). The cells were harvested by centrifugation at $3000 \mathrm{~g}$ for $10 \mathrm{~min}$ and resuspended in a buffer containing $1 \mathrm{M}$ MOPS and $15 \mathrm{mM} \mathrm{CaCl}$ (pH 6.5). One gram Hammarsten casein $(\mathrm{BDH})$ was dissolved in $100 \mathrm{ml}$ acetate phosphate buffer $(\mathrm{pH} \mathrm{6.5)}$ and the buffered casein was incubated at $28^{\circ} \mathrm{C}$ for $1 \mathrm{~h}$. The cell suspensions $(0.5 \mathrm{ml})$ were added to $10 \mathrm{ml}$ casein solution and the mixture was incubated at $28{ }^{\circ} \mathrm{C}$ with gentle agitation. Samples $(1 \mathrm{ml})$ were aseptically removed at intervals and placed in $1.5 \mathrm{ml}$
Eppendorf tubes. The cells were centrifuged and $500 \mu \mathrm{l}$ supernatant transferred to new tubes. A volume of $500 \mu$ licecold $10 \%$ trichloroacetic acid was added, vortexed and allowed to precipitate for $30 \mathrm{~min}$ on ice. Precipitated material was removed by centrifugation, and $200 \mu$ l supernatant added to $750 \mu \mathrm{l}$ potassium borate buffer ( $\mathrm{pH} 9.5$ ) and $400 \mu \mathrm{l} 0.1 \%$ 2,4,6-trinitrobenzenesulfonic acid (TNBS). Following incubation at $37^{\circ} \mathrm{C}$ for $1 \mathrm{~h}$ to allow colour development, the reaction was stopped by addition of $800 \mu \mathrm{l} 1 \mathrm{M} \mathrm{NaH} \mathrm{NO}_{4}$ containing $18 \mathrm{mM} \mathrm{Na} \mathrm{SO}_{3}$. Colour development was read at $\lambda=420 \mathrm{~nm}$ (Beckman DU 640 spectrophotometer, path length $1 \mathrm{~cm}$ ) within $20 \mathrm{~min}$ and related to glycine equivalents released using a standard curve.

Detection of siderophores, hydrogen cyanide and phloroglucinols. Production of siderophores was assessed on SA plates containing the iron chelator ethylenediamine-di $(o-$ hydroxyphenylacetic acid) (EDDHA; $250 \mu \mathrm{M}$ ) and on chrome azurol S (Schwyn \& Neilands, 1987) indicator medium. Hydrogen cyanide production was assayed qualitatively, as described by Castric \& Castric (1983). The polyketide 2,4diacetylphloroglucinol was studied by HPLC analysis (Shanahan et al., 1992).

Genetic manipulations. Mobilization of plasmids between $E$. coli and $S$. maltophilia W81 was performed using the helper plasmid pRK2013 (Ditta et al., 1980), transformation of E. coli DH5 $\alpha$-using the standard $\mathrm{CaCl}_{2}$ heat-shock method, and 
recombinant DNA manipulations as outlined by Sambrook et al. (1989). All digestions and ligations were done using enzymes from Promega or Boehringer Mannheim.

$\mathrm{Tn} 5$ mutagenesis of the $\mathrm{Sm}^{\mathrm{r}}$ strain W81 was performed using pSUP102:: Tn5-B50 (Tcr ; Simon et al., 1983b, 1989) or with pRL764cd, a tetracycline-resistant derivative of pRL764 (Cohen et al., 1997), as previously described by Kragelund $e t$ al. (1995). The resulting $\mathrm{Tn} 5$ insertion derivatives $\left(\mathrm{Sm}^{\mathrm{r}} \mathrm{Tc}^{\mathrm{r}}\right)$ were screened for chitinolytic and proteolytic activities on plates, as described above. Mutants deficient in the production of protease (W81M1), chitinase (W81M2) or both enzymes (W81A1) were identified.

Restoration of W81A1 lytic enzyme activity was performed as follows. A genomic library of W 81 was constructed using the IncQ broad-host-range cosmid pSUP106 (Simon et al., 1983a), as described by Fenton et al. (1992). Ligation products were transfected into E. coli LE392 (Sambrook et al., 1989) using the bacteriophage-head-based Packagene system (Promega). Resultant $\mathrm{Cm}^{\mathrm{r}} \mathrm{Tc}^{\mathrm{r}}$ colonies were mated with W81A1, using HB101(pRK2013) to provide helper functions. Transconjugants were screened for restored chitinolytic and proteolytic activities, as described above, and W81A1(pCU800) with restored enzyme activity was obtained.

DNA-DNA hybridization procedures. Total genomic DNA was prepared by caesium chloride/ethidium bromide equilibrium density gradient centrifugation (Sambrook et al., 1989). DNA was restricted with EcoRI and immobilized on Hybond-N + nylon membranes (Amersham) by capillary blotting. DNA probes, i.e. Tn5-B50, Tn5-764cd and the pCU800 genomic insert, were isolated from agarose gels using a QIAEX extraction kit (QIAGEN). Probe DNA was radioactively labelled using a Primagene labelling kit (Promega). Hybridization experiments were completed, according to the manufacturer's recommendations, using an ECL Direct $\mathrm{Nu}$ cleic Acid Labelling and Detection System (Amersham).

Sequence analysis. DNA flanking the inserted Tn5-764cd was cloned from the protease-deficient mutant W81M1 using a modification of the method described by Wolk et al. (1991). Total genomic DNA was prepared by caesium chloride/ ethidium bromide equilibrium density gradient centrifugation (Sambrook et al., 1989). DNA was digested using the restriction enzyme Dral, which does not cut the transposon. The resulting fragments were self-ligated and transformed into E. coli DH5 $\alpha$. DNA sequence flanking the inserted transposon was determined using unique primers (GENOSYS, Cambridge, UK) homologous to the left $\left(5^{\prime}\right.$ TACTAGATTCAATGCTATCAATGAG $3^{\prime}$ ) and right ( $5^{\prime}$ AGGAGGTCACATGGAATATCAGAT $3^{\prime}$ ) ends of Tn5-764cd. These primers were designed based on previously described shorter primers (Black et al., 1993; Fernandez-Pinas et al., 1994). PCR fragments for automated sequence analysis were sequenced using an ABI PRISM Dye Terminator Cycle Sequencing Ready Reaction Kit (Perkin-Elmer) and the following conditions: $96^{\circ} \mathrm{C} 30 \mathrm{~s}, 50{ }^{\circ} \mathrm{C} 15 \mathrm{~s}, 60^{\circ} \mathrm{C} 4 \mathrm{~min}$, for 25 cycles, and were analysed on an ABI PRISM 310 Genetic Analyser (PerkinElmer). Similarities in the DNA and protein databases were searched for using the BLAST algorithm (Altschul et al., 1990).

Susceptibility of $\boldsymbol{P}$. ultimum to commercial and W81-produced chitinases and proteases in vitro. The effect of commercial microbial chitinase and Proteinase $\mathrm{K}$ on $P$. ultimum was studied using mycelium grown for $3-5 \mathrm{~d}$ in liquid LB (at $28^{\circ} \mathrm{C}$, without shaking). The mycelium was collected using a sterile metal spatula, washed in quarterstrength Ringer's solution, resuspended in fresh LB broth containing chitinase from Serratia marcescens (Sigma C-1525, EC 3.2.1.14) $\left(0 \cdot 5-1 \cdot 0\right.$ units $\left.\mathrm{ml}^{-1}\right)$ or Proteinase K (Sigma P-8044, EC 3.4.21.14) $\left(0 \cdot 5-1 \cdot 0\right.$ units $\left.\mathrm{ml}^{-1}\right)$ and incubated for $48 \mathrm{~h}$ at $28^{\circ} \mathrm{C}$.

Some of the samples were used for microscopic examination of the mycelium, either in wet mounts or after staining with cationic (methylene blue, crystal violet) or anionic (safranin, fuchsin acid, Congo red, eosin yellow) dyes. The remaining samples were used to study the ability of the fungus to grow, as follows. The mycelium was washed in quarter-strength Ringer's solution and placed in the centre of LB, PDA, MEA or NA plates. Fungal growth was assessed after incubating the plates for $7 \mathrm{~d}$ at $28^{\circ} \mathrm{C}$. In all assays, untreated fungal mycelium was used as a negative control.

The experiments were also performed using concentrated cellfree (filter-sterilized) culture supernatants of W81 and its mutant derivatives instead of commercial chitinase and protease. The procedures were identical to those described above.

Soil microcosm experiments. The ability of wild-type W81 and its mutant derivatives to protect sugar beet from dampingoff disease was investigated in natural soil microcosms prepared using a sandy-loam soil obtained from the surface horizon of a field located near Brinny (Co. Cork, Ireland). The soil was chosen on the basis of (1) a history of damping-off disease of sugar beet at the site and (2) natural infestation of the soil by Pythium spp. [ $>1000$ propagules (g soil) ${ }^{-1}$ ], as shown using a Pythium-selective medium (Jeffers \& Martin, 1986). The soil was sieved through a $0.5 \mathrm{~cm}$ mesh screen prior to preparing the microcosms $(140 \mathrm{~g}$ soil per $7.5 \mathrm{~cm}$ diameter pot). Sugar beet seeds (cv. Accord) were inoculated by dipping them in cell suspensions (approximately $10^{6}$ c.f.u. per seed) of the bacteria studied. The latter included W81, W81M1, W81M2, W81A1, W81A1(pCU800) and the biocontrol agent P. fluorescens F113LacZY (Fedi et al., 1996). Controls consisted of seeds dipped in quarter-strength Ringer's solution (untreated control) or a solution containing the synthetic fungicides Previcur N (propamocarb; Schering) at $20 \mathrm{ml}(\mathrm{kg}$ seed) $)^{-1}$ and thiram at $7.5 \mathrm{~g}$ ( $\mathrm{kg}$ seed) ${ }^{-1}$ (commercial control). Nine seeds were sown per pot, at a depth of $1.5 \mathrm{~cm}$. Soil water content was adjusted to $70 \%$ saturation of the soil porosity every $3 \mathrm{~d}$ by spraying with distilled water. The pots were incubated in a growth chamber $\left(12^{\circ} \mathrm{C}, 16 \mathrm{~h}\right.$ photoperiod).

Infection of seeds by Pythium spp. was assessed daily during the first $7 \mathrm{~d}$ of the experiment, as follows. The seeds were removed from soil, washed in sterile quarter-strength Ringer's solution and incubated on the Pythium-selective agar of Jeffers \& Martin (1986) at $28^{\circ} \mathrm{C}$ for $48 \mathrm{~h}$ prior to scoring for the presence of Pythium spp. The percentage plant emergence was determined at $28 \mathrm{~d}$. Colonization of the sugar beet rhizosphere by the seed inoculants was assessed by colony counts on LB containing streptomycin and kanamycin (for wild-type W81), streptomycin, kanamycin and tetracycline [for W81M1, W81M2, W81A1 and W81A1(pCU800)], or SA containing XGal (for F113LacZY). Maintenance of pCU800 in W81A1 was determined by replica plating onto LB agar containing streptomycin, tetracyline and chloramphenicol. No colonies were found on the selective media when studying plants from the untreated control (detection limit of $10^{2}$ c.f.u. per root system).

Statistical aspects. All in vitro experiments were performed with three replicates of each treatment and were repeated at least three times. A randomized complete block design was used for the soil microcosm experiments, which were done four times. Seed infection by Pythium spp. was studied using ten seeds from each of three replications for each treatment at 
each sampling time. Plant emergence was investigated using nine replications. Each replication of each treatment consisted of one pot with nine seeds per pot. Six root systems were used to assess rhizosphere colonization of each strain at each sampling time, as described previously (Carroll et al., 1995). Percentages were arcsin-transformed and colony counts were log-transformed prior to analysis. Within each repeated experiment, analysis of variance was done at each sampling time using the General Linear Model procedures of the Statistical Analysis System (SAS Institute, Cary, NC, USA). When appropriate, differences between treatments were studied using Fisher's LSD test. All analyses were performed at $P=$ 0.05 level. Similar results were obtained each time the soil microcosm experiments were run and representative results obtained in one of the four runs are shown in Table 2.

\section{RESULTS}

\section{S. maltophilia W81 inhibits $P$. ultimum in vitro and produces the extracellular enzymes chitinase and protease}

S. maltophilia W81 inhibited the growth of the fungal pathogen $P$. ultimum on the solid media LB agar, SA agar, PDA, MEA and NA. Colonies produced zones of clearing on plates containing chitin or casein, which is indicative of extracellular chitinase and protease activities, respectively. Extracellular chitinase and protease activities were observed even when readily available sources of carbon (i.e. glucose, sucrose, maltose, galactose, succinate, malate or fumarate) and/or nitrogen (i.e. ammonium sulphate) had been added to the chitin and skim milk plates, respectively. Production of extracellular protease and chitinase was not affected when the level of available iron in low-iron plates was increased by the addition of $100 \mu \mathrm{M} \mathrm{FeCl}_{3}$, despite the fact that iron influences extracellular protease activity in certain rhizobacteria (Dowling et al., 1996). Further characterization of W81 indicated that the strain does not produce the biocontrol metabolites 2,4-diacetylphloroglucinol or hydrogen cyanide. When grown on SA plus EDDHA or on chrome azurol S, W81 did not produce a siderophore (data not shown).

\section{Construction of mutants of S. maltophilia W81 deficient in extracellular lytic enzyme production and cloning of Tn5-tagged loci}

To determine if the inhibition of P. ultimum by W81 in vitro was linked to the ability of the bacterium to produce extracellular lytic enzymes, mutants of W81 deficient in the production of extracellular chitinase or protease were sought by mutagenesis with the transposons Tn5-B50 and Tn5-764cd. Approximately 15000 mutants were screened by replica plating for loss of lytic enzyme activity, and a Tn5-B50 induced mutant unable to produce either extracellular enzyme (W81A1) was identified (Table 2). Mutants incapable of extracellular protease production (W81M1) or extracellular chitinase production (W81M2) were only isolated following mutagenesis with Tn5-764cd (Table 2). The transposon Tn5-tagged locus of W81M1 was cloned from the genome, as described in Methods. A partial DNA sequence of the tagged locus was determined using primers corresponding to the left and right ends of the Tn5-764cd transposon.

Apart from lytic enzyme production, strains W81M1, W81M2 and W81A1 did not differ from W81 when compared using a variety of biochemical tests (aerobic acidification of glucose; production of catalase, oxidase,

Table 2. Evaluation of enzyme production by S. maltophilia, and biological control of $P$. ultimum under in vitro and natural soil microcosm conditions

\begin{tabular}{|c|c|c|c|c|c|}
\hline \multirow[t]{2}{*}{ Treatment } & \multicolumn{2}{|c|}{ Enzyme production } & \multicolumn{3}{|c|}{ Biological control } \\
\hline & $\begin{array}{l}\text { Lytic enzyme } \\
\text { production }\end{array}$ & $\begin{array}{l}\text { Proteolytic } \\
\text { activity" } \dagger\end{array}$ & $\begin{array}{l}\text { Inhibition of } \\
\text { P. ultimum } \\
\text { growth in } \\
\text { vitro }\end{array}$ & $\begin{array}{c}\text { Pythium-free } \\
\text { seeds after 1 d } \\
\text { in soil }(\%) \dagger\end{array}$ & $\begin{array}{c}\text { Emerged } \\
\text { sugarbeet } \\
\text { plants after } \\
28 \mathrm{~d} \text { in soil } \\
(\%) \dagger\end{array}$ \\
\hline Commercial control & - & - & + & $100^{a}$ & $72(4)^{a}$ \\
\hline Untreated control & - & - & - & $5(5)^{b}$ & $38(6)^{c}$ \\
\hline F113LacZY & - & - & + & $90(4)^{a}$ & $59(4)^{b}$ \\
\hline W81 & $\begin{array}{c}\text { Chitinase, } \\
\text { protease }\end{array}$ & $6.5(0 \cdot 6)^{a}$ & + & $87(9)^{a}$ & $64(7)^{a b}$ \\
\hline W81M1 & Chitinase & $0 \cdot 9(0 \cdot 6)^{b}$ & - & $20(6)^{b}$ & $38(8)^{c}$ \\
\hline W81M2 & Protease & $7 \cdot 3(0 \cdot 8)^{a}$ & + & $84(6)^{a}$ & $57(3)^{b}$ \\
\hline W81A1 & None & $0 \cdot 8(0 \cdot 2)^{b}$ & - & $30(11)^{b}$ & $36(4)^{c}$ \\
\hline W81A1(pCU800) & $\begin{array}{c}\text { Chitinase, } \\
\text { protease }\end{array}$ & $6.4(0.4)^{a}$ & + & $86(8)^{a}$ & $58(4)^{b}$ \\
\hline
\end{tabular}

* One unit of activity corresponds to $1 \mathrm{nmol}$ glycine equivalents released ( $\mathrm{ml}$ cell-free supernatant $)^{-1} \mathrm{~min}^{-1}$.

†Values given are means $( \pm \mathrm{SD})$. Within each column, values followed by a different letter are significantly different according to Fisher's LSD test at the $P=0.05$ level. 


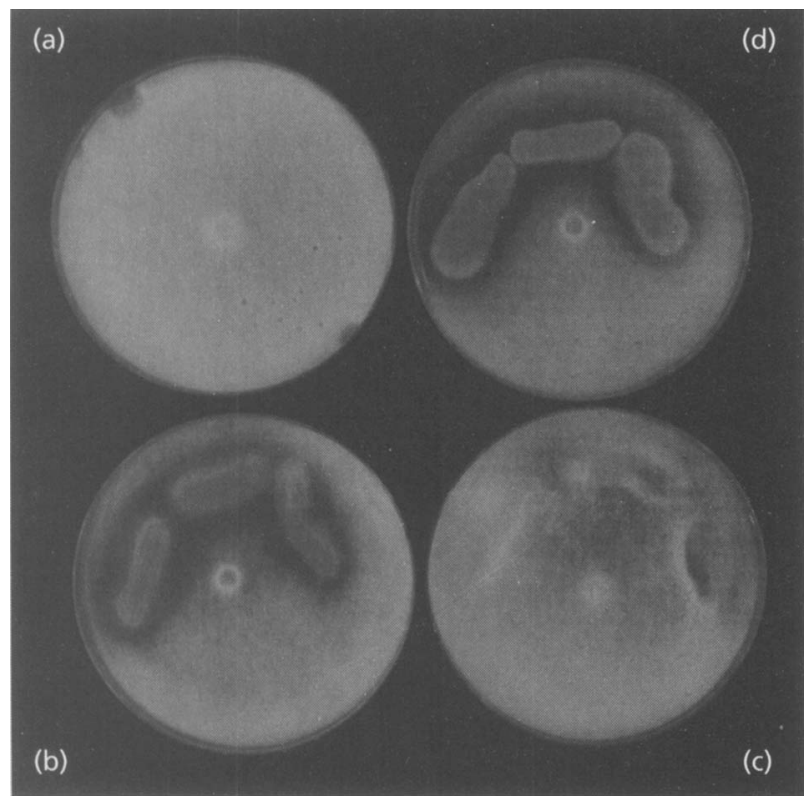

Fig. 1. Inhibition of growth of $P$. ultimum in vitro. $P$. ultimum inoculated alone completely covered the PDA plate (a). Wildtype S. maltophilia W81 inhibited growth of the fungus (b). Mutant W81A1 was unable to inhibit fungal growth (c), unlike W81A1(pCU800) with restored lytic enzyme production (d).

gelatinase, casein protease, DNase; and assimilation of acetate, citrate, malate, glucose, mannose, maltose, $\mathrm{N}$ acetylglucosamine and maltose) and growth curves in liquid $\mathrm{LB}$ and SA.

\section{Sequence analysis}

The amino acid sequences deduced from the primary DNA sequence were compared to sequences in the nonredundant protein databases at the National Centre for Biological Information (NCBI). Results indicated that the region in which $T$ n5-764cd has inserted in the protease-deficient mutant W81M1 shows $39 \%$ identity between residues 260 and 370 of the acrosin trypsin-like serine peptidase (S12968). Further shared similarities with other S8, S21, C1 and M4 peptidase families suggest that the insertion of $T n 5-764 \mathrm{~cd}$ caused a mutation in a gene encoding a proteolytic enzyme.

\section{Construction of a cosmid library of S. maltophilia W81 and complementation of the mutant W81A1}

Introduction of a $B a m \mathrm{HI}$ fragment of approximately $15 \mathrm{~kb}$ from a cosmid library of W81 into the chitinaseand protease-negative mutant W81A1 resulted in the generation of the complemented derivative W81A1(pCU800) with restored ability to produce the two extracellular lytic enzymes (Table 2). The presence of pCU800 in W81A1 also restored the ability to inhibit P. ultimum in vitro (Fig. 1). Southern hybridizations of W81M1, W81M2 and W81A1 using Tn5-764cd, Tn5$\mathrm{B} 50$ and the $15 \mathrm{~kb}$ genomic insert as ${ }^{35} \mathrm{~S}$-labelled probes demonstrated that the complementing insert originated from the same genomic region of W81 in which the transposon is inserted in W81A1. However, the three distinct mutant phenotypes associated with W81M1, W81M2 and W81A1 were due to transposon insertions into different genetic regions. Introduction of pCU800 into P. fluorescens M114 and F113, two chitinasenegative strains in which extracellular protease is ironregulated, did not confer chitinolytic activity or ironindependent proteolytic activity.

\section{Detection and quantification of extracellular lytic enzymes in cell-free culture supernatants of wild- type W81 and its mutant derivatives}

Concentrated cell-free supernatants from SA and LB cultures of S. maltophilia W81, W81M1, W81M2, W81A1 and W81A1(pCU800) were used to further investigate the ability of W81 and its mutant derivatives to produce extracellular chitinase and protease in vitro. Concentrated cell-free supernatants from cultures of wild-type W81 displayed chitinase and protease activity on plates, in SDS-PAGE gels and in non-denaturing PAGE gels. In contrast, concentrated cell-free supernatants from cultures of the mutants W81M1, W81M2 and W81A1 did not display proteolytic, chitinolytic or either lytic enzyme activity, respectively. However, plate, gel and biochemical results indicated that chitinase and protease activity had been restored in the complemented derivative W81A1(pCU800). Quantification of extracellular protease activity in cell-free culture supernatants demonstrated that wild-type W81, W81M2 and W81A1(pCU800) produced similar levels of active enzyme (Table 2 ).

\section{Role of lytic enzymes in inhibition of $P$. ultimum by S. maltophilia W81 in vitro}

To determine whether lytic enzymes produced by W81 were responsible for the ability of the strain to inhibit $P$. ultimum in vitro, mycelium of the fungal pathogen was incubated in the presence of cell-free supernatants from cultures of W81, W81M1, W81M2, W81A1 or the complemented mutant W81A1(pCU800). Whereas fungal mycelium previously exposed to W81A1 or W81M1 cell-free culture supernatant (or from the control) displayed intact cell walls, the cell walls of mycelium incubated in the presence of cell-free culture supernatants from W81, W81M2 or the complemented derivative W81A1(pCU800) were partially or completely degraded and intracellular fungal constituents had been released from the hyphae (Fig. 2). Furthermore, there were differences observed between the samples of mycelium when microscopic examinations were performed using wet mounts, or after staining with the anionic dyes safranin, eosin yellow, acid fuchsin or Congo red. No differences were observed following staining of mycelium with the cationic dyes methylene blue or crystal violet.

Similar experiments were performed using commercial chitinase and protease instead of cell-free culture supernatants. Incubation of $P$. ultimum in the presence of 

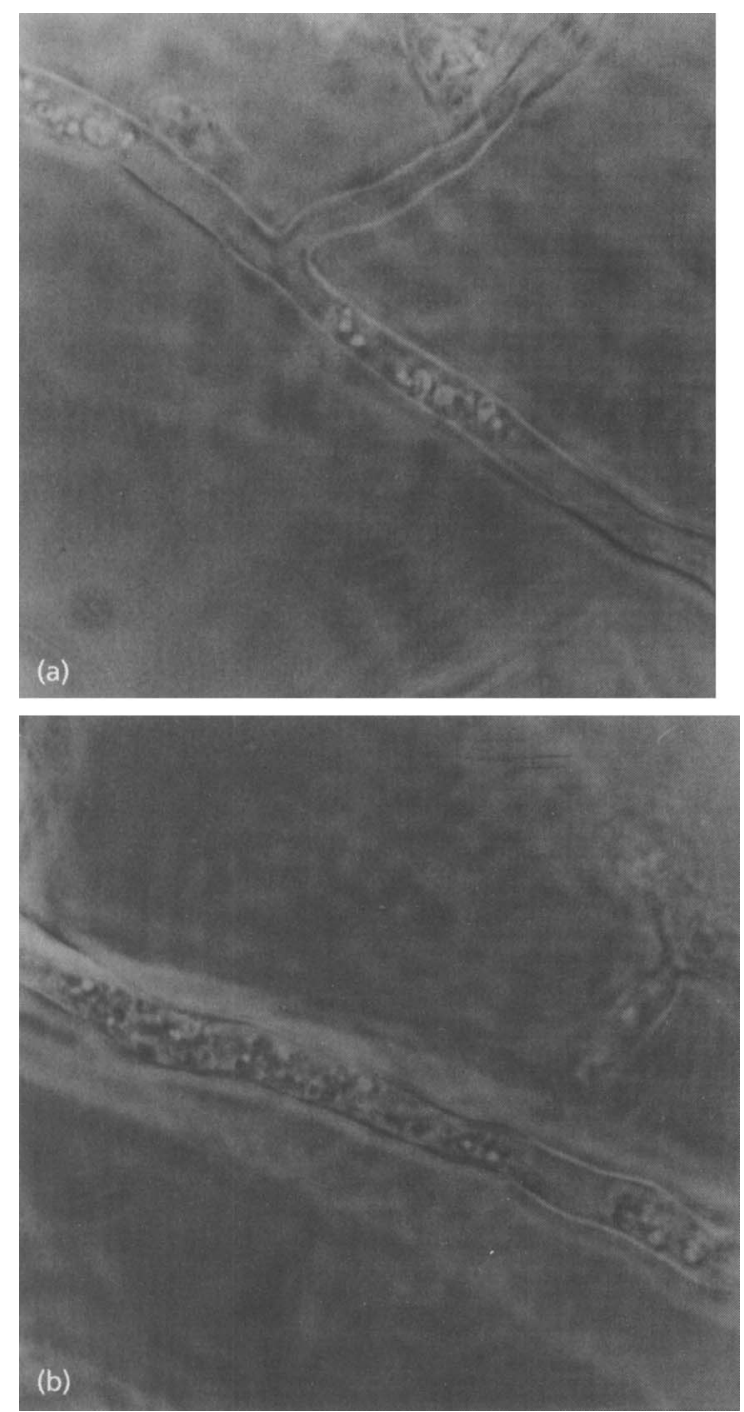

Fig. 2. Wet mounts of $P$. ultimum mycelium following incubation in cell-free culture supernatants of $S$. maltophilia W81 (a) or W81A1 (b). Whereas the mutants W81M1 or W81A1 deficient in proteolytic enzyme production had no detrimental effects on the fungal mycelium compared with the control (not shown), exposure to cell-free supernatants of wild-type W81, the chitinase-negative mutant W81M2 or W81A1(pCU800) resulted in disruption of the integrity of the cell wall and significant loss of intracellular constituents. Magnification $\times 1000$.

chitinase had no influence on the mycelium, but exposure of the fungus to protease resulted in the lysis of the hyphae similar to that obtained with cell-free culture supernatants of W81, W81M2 or W81A1(pCU800).

To confirm that the effect of W81 on P. ultimum, mediated through the production of extracellular protease, was fungicidal and not fungistatic, mycelium of the fungus previously incubated in the presence of cellfree culture supernatants of W81 or its mutants was washed and placed in the centre of plates containing LB agar, PDA, MEA or NA. Results indicated that fungal mycelium previously exposed to cell-free culture super- natants of W81, W81M2 or W81A1(pCU800) failed to grow on the plates. In contrast, $P$. ultimum previously incubated in the presence of cell-free culture supernatants of W81A1, W81M1 or from the untreated control gave rise to fungal growth on each medium. In conclusion, the fungicidal effect of $S$. maltophilia W81 on $P$. ultimum in vitro involved a proteolytic extracellular enzyme.

\section{Biocontrol ability of wild-type S. maltophilia W81 and its mutant derivatives in natural soil microcosms}

The ability of $S$. maltophilia W81 and its mutant derivatives to control the extent of damping-off of sugar beet was investigated in soil microcosms containing soil naturally infested by Pythium spp. Whereas $95 \%$ sugar beet seeds from the untreated control were colonized by Pythium spp. at $1 \mathrm{~d}$ after their introduction into soil, inoculation of seeds with W81 or W81M2 prior to sowing reduced the level of Pythium colonization to less than $20 \%$ (Table 2). This beneficial effect was not found in the W81A1 or W81M1 treatments, but seed inoculation with the complemented derivative W81A1(pCU800) resulted in a level of Pythium colonization of seeds similar to that in the proteolytic wildtype W81 and W81M2 treatment.

Percentage plant emergence was assessed $28 \mathrm{~d}$ after sowing. Plant emergence was higher in the W81 and W $81 \mathrm{M} 2$ treatments than in the untreated control, in the case of wild-type W81 reaching the level of protection achieved with synthetic fungicides in the commercial control (Table 2). The effects of W81 and W81M2 on damping-off disease was similar to that of $P$. fluorescens F113LacZY, a tagged derivative of the biocontrol strain F113 (Fedi et al., 1996). Unlike W81, W81A1 and W81M1 had no influence on damping-off of sugar beet, but the complemented derivative W81A1(pCU800) had a positive effect on plant emergence, which was similar to that of wild-type W81. In conclusion, the results from the soil microcosm experiment indicated that the biocontrol capability of S. maltophilia W81 in the sugar beet-Pythium pathosystem involved the ability of the bacterium to produce an extracellular protease.

\section{Colonization of the rhizosphere of soil-grown sugar beet by wild-type S. maltophilia W81 and its mutant derivatives}

The seed inoculants S. maltophilia W81, W81M1, W81M2, W81A1 and W81A1(pCU800) colonized the rhizosphere of soil-grown sugar beet to similar extents during the 28-d-long experiment, with all inoculants exhibiting an approximately 10 -fold decrease after the first $7 \mathrm{~d}$. This indicates that for W81A1 and W81M1, the lack of protection against damping-off was not due to a reduction in ecological fitness in the rhizosphere. Plasmid pCU800 was maintained in W81A1 at levels higher than $95 \%$. Colony counts for W81 and its mutants were essentially similar to those of the biocontrol pseudomonad F113LacZY. At each sampling time, colonies were chosen at random from the plates used for colony 
counts and their phenotype was investigated. All exhibited the same chitinase and protease activities on plates as those of the corresponding inoculants W81, W81M1, W81M2, W81A1 or W81A1(pCU800).

\section{DISCUSSION}

S. maltophilia is a typical soil inhabitant (Singer \& Debette, 1993) most often found associated with plants (McInroy \& Kloepper, 1994; Wilson \& Lindow, 1994; Berg et al., 1996). In the rhizosphere of rapeseed for instance, $S$. maltophilia is present at population levels of approximately $10^{7}$ c.f.u. (g root) ${ }^{-1}$ and represents a mean of $4 \%$ of the total culturable bacterial community (Berg et al., 1996). These bacteria have been the focus of much attention due to their potential for bioremediation (Blake et al., 1993). S. maltophilia has also been proposed for the protection of crops or turfgrass against fungal pathogens (Kobayashi et al., 1995; Berg et al., 1996) and as a bioherbicide against the weed downy brome (Mazzola et al., 1995). High levels of proteolytic activity are a prominent feature of $S$. maltophilia (Singer \& Debette, 1993).

The results presented in the current study indicate that S. maltophilia W81 can inhibit the growth of $P$. ultimum in vitro (Fig. 1). S. maltophilia W81, which does not produce fluorescent siderophores, HCN or 2,4-diacetylphloroglucinol (Phl) often associated with biocontrol pseudomonads, also has the ability to control the extent of damping-off of sugar beet in soil naturally infested by Pythium spp. (Table 2). Tn5-764cd insertion mutants of strain W81 were generated to investigate whether the biocontrol ability of the bacterium was linked to the production of extracellular lytic enzymes. These mutants proved incapable of extracellular protease (W81M1) or extracellular chitinase (W81M2) production. Cloning and sequence analysis of the genetic region into which Tn5-764cd had inserted in W/ $81 \mathrm{M} 1$ confirmed that the mutation occurred in a protease structural gene. Another mutant (W81A1) proved unable to produce either extracellular enzyme until lytic enzyme activity was restored through introduction of $15 \mathrm{~kb}$ of cosmidborne W81 genomic DNA (pCU800) (Table 2). In certain pseudomonads, regulation of extracellular enzyme and secondary metabolite production has been shown to involve two-component systems (Laville et al., 1992; Hrabak \& Willis, 1993; Gaffney et al., 1994; Sacherer et al., 1994). Since W81A1 is deficient in the production of both chitinase and protease enzymes, it may, therefore, prove to be a regulatory mutant.

Results obtained with W81, W81M1, W81M2, W81A1 and the complemented derivative W81A1(pCU800) under in vitro and natural soil microcosm conditions showed that the biocontrol ability of W81 was mediated by proteolytic enzyme production (Fig. 1, Table 2). Whereas commercial chitinase had no effect on $P$. ultimum in vitro, exposure of the fungus to commercial protease or the proteolytic cell-free culture supernatants of wild-type W81, W81M2 or W81A1(pCU800) resulted in degradation of proteinaceous cell-wall components and leakage of cell constituents (Fig. 2). Irreversible loss of mycelial growth ability further indicated that the antagonism of W81 towards P. ultimum was due to extracellular protease production. This finding is supported by the fact that in Oomycetes, such as P. ultimum, the cell wall is essentially free of chitin but does contain proteinaceous material (Mitchell \& Hurwitz, 1965; Haran et al., 1996). When assessed in soil microcosm assays, wild-type $S$. maltophilia W81 and its mutant derivatives colonized the rhizosphere of sugar beet at similar population levels, indicating that the absence of biocontrol ability was not due to a reduction in ecological fitness. The role of lytic enzymes in the ability of some strains of $S$. maltophilia to control phytopathogenic fungi has been hypothesized but, in contrast to this study, without genetic evidence (Kobayashi et al., 1995 ; Berg et al., 1996).

Early implementation of biocontrol mechanisms is required for effective control of Pythium spp. as germination of sporangia takes place rapidly in response to seed exudates (Nelson et al., 1988), allowing infection of the plant within hours of sowing (Stasz et al., 1980). Seed inoculation with W81 reduced the level of colonization of the seed by Pythium spp. $1 \mathrm{~d}$ after sowing, from $95 \%$ (untreated control) to $13 \%$ (Table 2). The level of fungal colonization of the seed up until germination (i.e. 4-7 d after sowing) remained below $20 \%$ in the proteolytic W81, W81M2 and W81A1(pCU800) treatments. Furthermore, wild-type W81, W81M2 and W81A1(pCU800) effectively reduced the extent of damping-off of sugar beet in soil microcosms (Table 2). The lack of biocontrol ability displayed by W81A1 and W81M1 can be attributed to the absence of extracellular protease activity. The coefficient of correlation between colonization of seed by Pythium spp. and percentage plant emergence (i.e. -0.94 ) was statistically significant. However, as many as $38 \%$ of all seeds colonized by Pythium spp. in the untreated control escaped dampingoff, an indication that fungal colonization of the seed/seedling is a prerequisite but is not sufficient for expression of the disease. In fact, $1 \mathrm{~d}$ after sowing, when studying crushed seeds previously surface-sterilized by sequential immersion in methanol and sodium hypochlorite and rinsed in sterile quarter-strength Ringer's solution, no internal infection of the seeds by Pythium spp. was found. The levels of plant protection conferred by the proteolytic bacterial treatments were similar to that achieved by $P$. fluorescens strain F113, the biocontrol activity of which is mediated through the production of the secondary metabolite 2,4-diacetylphloroglucinol (Fenton et al., 1992).

The exploitation of biocontrol agents in the field is limited by the sensitivity of biocontrol mechanisms to environmental conditions. For instance, biological control mediated through siderophore production is restricted to low-iron soil conditions (Scher \& Baker, 1982), whereas the majority of antimicrobial secondary metabolites require iron availability for production (Keel et al., 1989). The current study indicates that the biocontrol properties of $S$. maltophilia W81 against $P$. 
ultimum are mediated through production of an extracellular protease, which takes place under a wide range of in vitro conditions (including under high-iron conditions or in the presence of readily available carbon and nitrogen sources). These are obviously beneficial traits when considering the fact that W81, to be effective, needs to exert its biocontrol potential in the rhizosphere, a heterogeneous and fluctuating environment (Foster et al., 1983) in which the availability of nutrients (e.g. iron; Loper \& Henkels, 1997) may vary in space and time. In contrast, casein protease production is iron-regulated in many other rhizobacteria (Sexton et al., 1996; Dowling et al., 1996). In S. maltophilia strain C17, extracellular protease production is constitutive but repressed by the easily metabolizable substrate maltose, probably via catabolite repression (Singer \& Debette, 1993). However, repression by maltose does not occur in W81.

In conclusion, a reduction in damping-off of soil-grown sugar beet was achieved following seed treatment with S. maltophilia W81, which exhibits antagonism towards P. ultimum mediated by production of an extracellular protease. We propose that protease production may be useful in the construction of novel, genetically modified biocontrol inoculants. Further work will also evaluate the possibility of developing consortia of biocontrol agents in which strains with extracellular protease activity will be combined with others producing antifungal secondary metabolites.

\section{ACKNOWLEDGEMENTS}

The authors thank Pat Higgins and Liam Burgess for technical assistance. We are also grateful to A. Millcamps (MSU) for useful discussion. This work was supported in part by grants awarded by the Irish Science and Technology Agency Forbairt (SC-96-349) and the Biotechnology programmes of DGXII of the European Commission (BIO2-CT92-0084, BIO2-CT930196, BIO2-CT93-0053, BIO2-CT94-3001, BIO4-CT96-0027, BIO4-CT96-0181 and FMRX-CT96-0039) to F.O'G. and by the US Department of Energy (DE-FG 0290ER20021) and the NSF Center for Microbial Ecology (DIR 8809640) to F. J. de B.

\section{REFERENCES}

Alabouvette, C., Lemanceau, P. \& Steinberg, C. (1993). Recent advances in the biological control of fusarium wilts. Pestic Sci 37, 365-373.

Altschul, S. F., Gish, W., Miller, W., Myers, E. W. \& Lipman, D. J. (1990). Basic local alignment search tool. J Mol Biol 215, 403-410.

Atlas, R. M. \& Bartha, R. (1993). Microbial Ecology: Fundamentals and Applications. Redwood City, CA: Benjamin Cummings.

Becker, J. O. \& Schwinn, F. J. (1993). Control of soil-borne pathogens with living bacteria and fungi: status and outlook. Pestic Sci 37, 355-363.

Berg, G., Marten, P. \& Ballin, G. (1996). Stenotrophomonas maltophilia in the rhizosphere of oilseed rape: occurrence, characterisation and interaction with phytopathogenic fungi. Microbiol Res 151, 19-27.

Black, T. A., Cai, Y. \& Wolk, C. P. (1993). Spacial expression and autoregulation of het $R$, a gene involved in the control of heterocyst development in Anabaena. Mol Microbiol 9, 77-84.
Blake, R. C., II, Choate, D. M., Bardhan, S., Revis, N., Barton, L. L. \& Zocco, T. G. (1993). Chemical transformation of toxic metals by a Pseudomonas strain from a toxic waste site. Environ Toxicol Chem 12, 1365-1376.

Boyer, H. W. \& Roulland-Dussoix, D. (1969). A complementation analysis of the restriction and modification of DNA in Escherichia coli. J Mol Biol 41, 459-472.

Carroll, H., Moënne-Loccoz, Y., Dowling, D. N. \& O'Gara, F. (1995). Mutational disruption of the biosynthesis genes coding for the antifungal metabolite 2,4-diacetylphloroglucinol does not influence the ecological fitness of Pseudomonas fluorescens F113 in the rhizosphere of sugarbeets. Appl Environ Microbiol 61, 3002-3007.

Casadaban, M. \& Cohen, S. N. (1980). Analysis of gene control signals by DNA fusion and cloning in Escherichia coli. J Mol Biol 138, 179-207.

Castric, K. F. \& Castric, P. A. (1983). Method for rapid detection of cyanogenic bacteria. Appl Environ Microbiol 45, 701-702.

Chernin, L., Ismailov, Z., Haran, S. \& Chet, I. (1995). Chitinolytic Enterobacter agglomerans antagonistic to fungal plant pathogens. Appl Environ Microbiol 61, 1720-1726.

Cohen, M. F., Meeks, J. C., Cai, Y. A. \& Wolk, C. P. (1997). Transposon mutagenesis of heterocyst-forming filamentous cyanobacteria. Methods Enzymol (in press).

Cook, R. J. (1993). Making greater use of introduced microorganisms for biological control of plant pathogens. Annu Rev Phytopathol 31, 53-80.

Cook, R. J., Thomashow, L. S., Weller, D. M., Fujimoto, D., Mazzola, M., Bangera, G. \& Kim, D. S. (1995). Molecular mechanisms of defence by rhizobacteria against root disease. Proc Natl Acad Sci USA 92, 4197-4201.

Cronin, D., Moënne-Loccoz, Y., Fenton, A., Dunne, C., Dowling, D. N. \& O'Gara, F. (1997). Role of 2,4-diacetylphloroglucinol in the interactions of the biocontrol pseudomonad strain F113 with the potato cyst nematode Globodera rostochiensis. Appl Environ Microbiol 63, 1357-1361.

Ditta, G., Stanfield, S., Corbin, D. \& Helinski, D. R. (1980). Broad host range DNA cloning system for gram-negative bacteria: construction of a gene bank of Rhizobium meliloti. Proc Natl Acad Sci USA 77, 7347-7351.

Dowling, D. N. \& O'Gara, F. (1994). Metabolites of Pseudomonas involved in the biocontrol of plant disease. Trends Biotechnol 12, 133-141.

Dowling, D. N., Sexton, R., Fenton, A., Delany, I., Fedi, S., McHugh, B., Callanan, M., Moënne-Loccoz, Y. \& O’Gara, F. (1996). Iron regulation in plant-associated Pseudomonas fluorescens M114: implications for biological control. In Molecular Biology of Pseudomonads, pp. 502-511. Edited by T. Nakazawa, K. Furukawa, D. Haas \& S. Silver. Washington, DC: American Society for Microbiology.

Dunne, C., Delany, I., Fenton, A., Lohrke, S., Moënne-Loccoz, Y. \& O'Gara, F. (1996). The biotechnology and application of Pseudomonas inoculants for the biocontrol of phytopathogens. In Biology of Plant-Microbe Interactions, pp. 441-448. Edited by G. Stacey, B. Mullin \& P. M. Gresshoff. St Paul, MI : International Society for Molecular Plant-Microbe Interactions.

Dunne, C., Delany, I., Fenton, A. \& O'Gara, F. (1997). Mechanisms involved in biocontrol by microbial inoculants. Agronomie 16, 721-729.

Fedi, S., Brazil, D., Dowling, D. N. \& O’Gara, F. (1996). Construction of a modified mini-Tn5 lacZY non-antibiotic marker 
cassette: ecological evaluation of a lacZY marked Pseudomonas strain in the sugarbeet rhizosphere. FEMS Microbiol Lett 135, 251-257.

Fenton, A. M., Stephens, P. M., Crowley, J., O'Callaghan, M. \& O'Gara, F. (1992). Exploitation of gene(s) involved in 2,4diacetylphloroglucinol biosynthesis to confer a new biocontrol capability to a Pseudomonas strain. Appl Environ Microbiol 58, 3873-3878.

Fernandez-Pinas, F., Leganes, F. \& Wolk, C. P. (1994). A third locus required for the formation of heterocysts in Anabaena sp. strain PCC7120. J Bacteriol 176, 5277-5283.

Flores, A., Chet, I. \& Herrera-Estrella, A. (1997). Improved biocontrol activity of Trichoderma harzianum by overexpression of the proteinase-encoding gene prb1. Curr Genet 31, 30.

Foster, R. C., Rovira, A. D. \& Cock, T. W. (1983). Ultrastructure of the Root-Soil Interface. St Paul, MN: American Phytopathological Society.

Fridlender, M., Inbar, J. \& Chet, I. (1993). Biological control of soilborne plant pathogens by a $\beta-1,3$ glucanase-producing Pseudomonas cepacia. Soil Biol Biochem 25, 1211-1221.

Gaffney, T. D., Lam, S. T., Ligon, J. and 9 other authors (1994). Global regulation of expression of antifungal factors by a Pseudomonas fuorescens biological control strain. Mol PlantMicrobe Interact 7, 455-463.

Geremia, R. A., Goldman, G. H., Jacobs, D., Ardiles, W., Vila, S. B., Van Montagu, M. \& Herrera-Estrella, A. (1993). Molecular characterisation of the proteinase-encoding gene, prb1, related to mycoparasitism by Trichoderma harzianum. Mol Microbiol 8, 603-613.

Gould, W. D., Hagedorn, C., Bardinelli, T. R. \& Zablotowicz, R. M. (1985). New selective media for enumeration and recovery of fluorescent pseudomonads from various habitats. Appl Environ Microbiol 49, 28-32.

Haran, S., Schickler, H. \& Chet, I. (1996). Molecular mechanisms of lytic enzymes involved in the biocontrol activity of Trichoderma harzianum. Microbiology 142, 2321-2331.

Hrabak, E. M. \& Willis, D. K. (1993). Involvement of the lemA gene in production of syringomycin and protease by Pseudomonas syringae pv. syringae. Mol Plant-Microbe Interact 6, 368-375.

Jeffers, S. N. \& Martin, S. B. (1986). Comparison of two media selective for Phytophthora and Pythium spp. Plant Dis 70, 1038-1043.

Keel, C. \& Défago, G. (1997). Interactions between beneficial soil bacteria and root pathogens: mechanisms and ecological impact. In Multitrophic Interactions in Terrestrial Systems, pp. 27-46. Edited by A. C. Gange \& V.K. Brown. Oxford: Blackwell Scientific Publications.

Keel, C., Voisard, C., Berling, C. H., Kahr, G. \& Défago, G. (1989). Iron sufficiency, a prerequisite for the suppression of tobacco black root rot by Pseudomonas fluorescens strain CHA0 under gnotobiotic conditions. Phytopathology 79, 584-589.

Keel, C., Schnider, U., Maurhofer, M., Voisard, C., Laville, J., Burger, U., Wirthner, P., Haas, D. \& Défago, G. (1992). Suppression of root diseases by Pseudomonas fluorescens CHA0: importance of the bacterial secondary metabolite 2,4-diacetylphloroglucinol. Mol Plant-Microbe Interact 5, 4-13.

Kobayashi, D. Y., Gugielmoni, M. \& Clarke, B. B. (1995). Isolation of the chitinolytic bacteria Xanthomonas maltophilia and Serratia marcescens as biological control agents for summer patch disease of turfgrass. Soil Biol Biochem 27, 1479-1487.

Kragelund, L., Christoffersen, B., Nybroe, O. \& de Bruijn, F. J. (1995). Isolation of lux reporter gene fusions in Pseudomonas fluorescens DF57 inducible by nitrogen or phosphorus starvation. FEMS Microbiol Ecol 17, 95-106.

Laville, J., Voisard, C., Keel, C., Maurhofer, M., Défago, G. \& Haas, D. (1992). Global, stationary-phase control in Pseudomonas fluorescens mediating antibiotic synthesis and suppression of black root rot of tobacco. Proc Natl Acad Sci USA 89, 1562-1566.

Leeman, M., van Pelt, J. A., den Ouden, F. M., Heinsbroek, M., Bakker, P. A. H. M. \& Schippers, B. (1995). Induction of systemic resistance by Pseudomonas fluorescens in radish cultivars differing in susceptibility to fusarium wilt, using a novel bioassay. Eur $J$ Plant Pathol 101, 655-664.

Lemanceau, P. \& Alabouvette, C. (1991). Biological control of fusarium diseases by fluorescent Pseudomonas and non-pathogenic Fusarium. Crop Prot 10, 279-286.

Loper, J. E. \& Henkels, M. D. (1997). Availability of iron to Pseudomonas fluorescens in rhizosphere and bulk soil evaluated with an ice nucleation reporter gene. Appl Environ Microbiol 63, 99-105.

Lorito, M., Peterbauer, C., Hayes, C. K. \& Harman, G. E. (1994). Synergistic interaction between fungal cell wall degrading enzymes and different antifungal compounds enhances inhibition of spore germination. Microbiology 140, 623-629.

Mclnroy, J. A. \& Kloepper, J. W. (1994). Studies on indigenous endophytic bacteria on sweet corn and cotton. In Molecular Ecology of Rhizosphere Microorganisms, pp. 19-28. Edited by F. O'Gara, D. N. Dowling \& B. Boesten. Weinheim: VCH.

McKellar, R. C. (1981). Development of off-flavour in ultra-high temperature and pasteurized milk is a function of proteolysis. J Dairy Sci 64, 2138-2145.

Mazzola, M., Stahlman, P. W. \& Leach, J. E. (1995). Application method affects the distribution and efficacy of rhizobacteria suppressive of downy brome (Bromus tectorum). Soil Biol Biochem 27, 1271-1278.

Mitchell, R. \& Hurwitz, E. (1965). Suppression of Pythium debaryanum by lytic rhizosphere bacteria. Phytopathology 55, 156-158.

Nelson, E. B., Harman, G. E. \& Nash, G. T. (1988). Enhancement of Trichoderma induced biological control of Pythium seed rot and pre-emergence damping-off of peas. Soil Biol Biochem 20, 145-150.

Oppenheim, A. B. \& Chet, I. (1992). Cloned chitinases in fungal plant-pathogen control strategies. Trends Biotechnol 10, 392394.

O'Sullivan, D. J. \& O'Gara, F. (1992). Traits of fluorescent Pseudomonas spp. involved in suppression of plant root pathogens. Microbiol Rev 56, 662-676.

Palleroni, N. J. \& Bradbury, J. F. (1993). Stenotrophomonas, a new bacterial genus for Xanthomonas maltophilia (Hugh 1980) Swings et al., 1983. Int J Syst Bacteriol 43, 606-609.

Sacherer, P., Défago, G. \& Haas, D. (1994). Extracellular protease and phospholipase $\mathrm{C}$ are controlled by the global regulatory gene gacA in the biocontrol strain Pseudomonas fluorescens CHA0. FEMS Microbiol Lett 116, 155-160.

Sambrook, J., Fritsch, E. F. \& Maniatis, T. (1989). Molecular Cloning: a Laboratory Manual, 2nd edn. Cold Spring Harbor, NY : Cold Spring Harbor Laboratory.

Scher, F. M. \& Baker, R. (1982). Effect of Pseudomonas putida and a synthetic iron chelator on induction of soil suppressiveness to Fusarium wilt pathogens. Phytopathology 72, 1567-1573.

Schwyn, B. \& Neilands, J. B. (1987). Universal chemical assay for the detection and determination of siderophores. Anal Biochem $160,47-56$. 
Sexton, R., Gill, P. R., Jr, Dowling, D. N. \& O'Gara, F. (1996). Transcriptional regulation of the iron-responsive sigma factor gene pbrA. Mol Gen Genet 250, 50-58.

Shanahan, P., O'Sullivan, D. J., Simpson, P., Glennon, J. D. \& O'Gara, F. (1992). Isolation of 2,4-diacetylphloroglucinol from a fluorescent pseudomonad and investigation of physiological parameters influencing its production. Appl Environ Microbiol 58, 353-358.

Simon, R., Priefer, U. \& Puhler, A. (1983a). Vector plasmids for in vivo and in vitro manipulations of gram-negative bacteria. In Molecular Genetics of the Bacteria-Plant Interaction, pp. 98-106. Edited by A. Pühler. Berlin \& Heidelberg: Springer.

Simon, R., Priefer, U. \& Püler, A. (1983b). A broad host range mobilisation system for in vivo genetic engineering: transposon mutagenesis in gram-negative bacteria. Bio/Technology 1, 784 791.

Simon, R., Quandt, J. \& Klipp, W. (1989). New derivatives of transposon $\operatorname{Tn} 5$ suitable for mobilisation of replicons, generation of operon fusions and induction of genes in gram-negative bacteria. Gene 80, 161-169.

Singer, E. \& Debette, J. (1993). Nutritional factors controlling exocellular proteinase production in a soil-isolated Xanthomonas maltophilia strain. J Basic Microbiol 33, 113-121.

Stasz, T. E., Harman, G. E. \& Marx, G. A. (1980). Time and site of infection of resistant and susceptible germinating pea seeds by Pythium ultimum. Phytopathology 70, 730-733.
Swings, J., De Vos, P., Van den Mooter, M. \& De Ley, J. (1983). Transfer of Pseudomonas maltophilia Hugh 1981 to the genus Xanthomonas as Xanthomonas maltophilia (Hugh 1981) comb. nov. Int J Syst Bacteriol 33, 409-413.

Thomashow, L. S. \& Weller, D. M. (1988). Role of a phenazine antibiotic from Pseudomonas fluorescens in biological control of Gaeumannomyces graminis var. tritici. J Bacteriol 170, 34993508.

Voisard, C., Bull, C. T., Keel, C., Laville, J., Maurhofer, M., Schnider, U., Défago, G. \& Haas, D. (1994). Biocontrol of root diseases by Pseudomonas fluorescens CHA0: current concepts and experimental approaches. In Molecular Ecology of Rhizosphere Microorganisms, pp. 67-69. Edited by F. O'Gara, D. N. Dowling \& B. Boesten. Weinheim: VCH.

Wilson, M. \& Lindow, S. E. (1994). Coexistence among epiphytic bacterial populations mediated through nutritional resource partitioning. Appl Environ Microbiol 60, 4468-4477.

Wolk, C. P., Cai, Y. \& Panoff, J. M. (1991). Use of a transposon with luciferase as a reporter to identify environmentally responsive genes in a cyanobacterium. Proc Natl Acad Sci USA 88, $5355-5359$

Received 11 July 1997; revised 26 August 1997; accepted 3 September 1997. 